\title{
Efficiency of Sulfur-Coated Urea and Potassium Chloride Compounds Applied to Stargrass Growing on an Ultisol under Humid Tropical Conditions ${ }^{1,2}$
}

\author{
Fernando Abruña, Jacinto Figarella, and Rubén Caro-Costas ${ }^{3}$
}

\begin{abstract}
The efficiency of various S-coated urea and $\mathrm{KCl}$ compounds applied to stargrass growing on an Ultisol under humid tropical conditions was determined. Applying $\mathrm{N}$ as urea in six applications yearly or in one application of S-coated urea compounds TV 1415 and 1255 resulted in higher recovery of fertilizer $\mathrm{N}$ compared to urea in one application. Applying $\mathrm{K}$ as $\mathrm{KCl}$ in six applications yearly resulted in higher recovery of fertilizer $\mathrm{K}$ in the forage than when applied in one application. The various $\mathrm{S}$-coated $\mathrm{KCl}$ compounds did not result in higher recovery of fertilizer $\mathrm{K}$ than did $\mathrm{KCl}$ in one application.
\end{abstract}

\section{INTRODUCTION}

Tropical grasses growing on Ultisols under humid tropical conditions in Puerto Rico responded strongly to $\mathrm{N}$ fertilization up to $448 \mathrm{~kg} / \mathrm{ha}$ ( 400 $\mathrm{lb} / \mathrm{acre})$ yearly as shown by Vicente-Chandler et al. $(3,4,5,6,7,8)$ and Caro-Costas et al. $(1,2)$. An average of $52.4 \%$ of the $\mathrm{N}$ applied as ammonium sulphate at rates of 224 to $448 \mathrm{~kg} / \mathrm{ha}$ (200 to $400 \mathrm{lb} / \mathrm{acre}$ ) yearly in six equal applications was recovered by the grasses. VicenteChandler et al. (9) found that ammonium sulphate, sodium nitrate, ammonium nitrate, urea, and ammonium hydroxide produced similar forage yields, but the latter two were less efficient providers of $\mathrm{N}$ as shown by a lower recovery of fertilizer $\mathrm{N}$ in the forage.

Tropical grasses growing on Ultisols under humid tropical conditions in Puerto Rico also responded strongly to fertilization with K. VicenteChandler et al. (10) found that yields increased sharply with $\mathrm{K}$ rates from 224 to $448 \mathrm{~kg} / \mathrm{ha}$ ( 200 to $400 \mathrm{lb} / \mathrm{acre}$ ) yearly. An average of $74.5 \%$ of the $\mathrm{K}$ applied at the rate of $448 \mathrm{~kg} / \mathrm{ha}$ ( $400 \mathrm{lb} /$ acre) yearly was recovered in the

${ }^{1}$ Manuscript submitted to Editorial Board June 11, 1975.

${ }^{2}$ This research covers work conducted cooperatively by the Agricultural Research Service, USDA, and the Agricultural Experiment Station, Mayagüez Campus, University of Puerto Rico. Río Piedras, P.R. Appreciation is expressed to Dr. David Mays of TVA for providing the fertilizer materials and advice on their use.

${ }^{3}$ Soil Scientist, Chemist, Agricultural Research Service, USDA, and Associate Agronomist in cooperation between the Agricultural Research Service, USDA, and the Agricultural Experiment Station, Río Piedras, P.R., respectively. 
forage. Vicente-Chandler et al. (9) found that pangolagrass responded to $\mathrm{K}$ applications at nine different sites representing seven soil types in Puerto Rico.

This paper presents the results of two adjacent, concurrently run experiments to determine the efficiency of various S-coated urea and $\mathrm{KCl}$ compounds compared to the uncoated materials when applied to stargrass growing on an Ultisol under humid tropical conditions in Puerto Rico.

\section{MATERIALS AND METHODS}

The experiments were conducted at Orocovis at an elevation of about $600 \mathrm{~m}(2,000 \mathrm{ft})$ with a mean annual temperature of about $24^{\circ} \mathrm{C}\left(75^{\circ} \mathrm{F}\right)$ and seasonal variations of less than $4^{\circ} \mathrm{C}\left(10^{\circ} \mathrm{F}\right)$. Monthly rainfall for the

TABLE 1.-Monthly rainfall during the 2-year experimentation with S-coated urea and $\mathrm{KCl}$ at Orocovis

\begin{tabular}{lrrrr}
\hline \multicolumn{1}{c}{ Month } & \multicolumn{2}{c}{ First year } & \multicolumn{2}{c}{ Second year } \\
\hline & $C m$ & In & \multicolumn{1}{c}{ In } & In \\
January & 20.8 & 8.2 & 10.7 & 4.2 \\
February & 4.6 & 1.8 & 4.1 & 1.6 \\
March & 8.9 & 3.5 & 31.0 & 12.2 \\
April & 8.1 & 3.2 & 26.4 & 10.4 \\
May & 53.3 & 21.0 & 9.9 & 3.9 \\
June & 17.8 & 7.0 & 2.3 & .9 \\
July & 23.4 & 9.2 & 1.5 & .6 \\
August & 16.5 & 6.5 & 14.0 & 5.5 \\
September & 27.9 & 11.0 & 7.4 & 2.9 \\
October & 46.7 & 18.4 & 22.6 & 8.9 \\
November & 32.5 & 12.8 & 19.3 & 7.6 \\
December & 33.0 & 13.0 & 12.2 & 4.8 \\
\multicolumn{1}{c}{ Total } & 293.5 & 115.6 & 161.4 & 63.5 \\
\hline
\end{tabular}

duration of the experiments is shown in table 1. Annual rainfall was 293.5 and $161.4 \mathrm{~cm}$ (115.6 and $63.5 \mathrm{in}$ ) during the first and second years, respectively.

The soil was Humatas clay (Ultisol) with $3.2 \%$ organic matter and 13.4 meq of exchange capacity per $100 \mathrm{~g}$ of soil. The soil contained $204 \mathrm{~kg} / \mathrm{ha}$ (182 lb/acre) of exchangeable $\mathrm{K}$ and $74 \mathrm{~kg} / \mathrm{ha}$ (66 lb/acre) of $\mathrm{K}$ extractable with hot nitric acid in the upper 6 in of soil.

A randomized block design was used in both experiments with all treatments replicated five times. The treatments, shown in table 2 and 3 , compared urea and $\mathrm{KCl}$ applied in one and six applications yearly to various $\mathrm{S}$-coated urea and $\mathrm{KCl}$ products provided by TVA applied once yearly. All these materials contained $.25 \%$ coal tar as a microbicide. 
Plots were $3.5 \times 3.5 \mathrm{~m}$ surrounded by ditches to prevent fertilizer from washing from one plot to another. Stargrass (Cynodon nlemfuensis) ${ }^{4}$ was grown in all plots and harvested by cutting every 60 days. Dry matter yields were determined and samples from each cutting analyzed for $\mathrm{N}$ and $\mathrm{K}$.

The soil in all plots was limed to $\mathrm{pH} 6$ at the start of the experiment. All plots received $224 \mathrm{~kg} / \mathrm{ha}$ (200 lb/acre) of P yearly in one application. In the experiment on $\mathrm{N}$ sources, $\mathrm{N}$ from the various compounds was applied at a rate of $336 \mathrm{~kg} / \mathrm{ha}$ ( $300 \mathrm{lb} / \mathrm{acre}$ ) yearly and $\mathrm{K}$ at a rate of 672 $\mathrm{kg} / \mathrm{ha}(600 \mathrm{lb} / \mathrm{acre})$ yearly. In the experiment on $\mathrm{K}, \mathrm{K}$ from the various

TABLE 2.-Efficiency of various forms of urea applied to stargrass growing on an Ultisol in the humid mountain region of Puerto Rico

\begin{tabular}{|c|c|c|c|c|c|c|c|}
\hline \multirow{3}{*}{ Treatment $^{1}$} & \multicolumn{4}{|c|}{ Yield of dry forage } & \multicolumn{3}{|c|}{$\begin{array}{l}\text { Fertilizer } N \text { recovered } \\
\text { in forage }\end{array}$} \\
\hline & \multicolumn{2}{|c|}{ First year } & \multicolumn{2}{|c|}{ Second year } & \multirow{2}{*}{$\begin{array}{l}\text { First } \\
\text { year } \\
\ddots\end{array}$} & \multirow{2}{*}{$\begin{array}{c}\text { Second } \\
\text { year } \\
\%\end{array}$} & \multirow{2}{*}{$\begin{array}{c}\text { Total } \\
\pi_{c}\end{array}$} \\
\hline & $K g / h a$ & Lblacre & Kg/ha & Lb/acre & & & \\
\hline No $\mathrm{N}$ applied & 22,619 & 20,187 & 9,251 & 8,260 & - & - & - \\
\hline $\begin{array}{l}\text { Urea in one applica- } \\
\text { tion yearly }\end{array}$ & 25,442 & 22,116 & 9,442 & 8,430 & 24.9 & 1.2 & 26.1 \\
\hline $\begin{array}{l}\text { Urea in six applica- } \\
\text { tions yearly }\end{array}$ & 29,949 & 26,740 & 11,435 & 10,210 & 39.1 & 11.3 & 50.4 \\
\hline $\begin{array}{l}\text { S-coated Urea } 1415 \\
(28.6 \% \text { coating }) \\
\text { once a year }\end{array}$ & 27,955 & 24,960 & 11,738 & 10,480 & 37.0 & 11.7 & 48.7 \\
\hline $\begin{array}{l}\text { S-coated Urea } 1005 \\
(20.7 \% \text { coating) } \\
\text { once a year }\end{array}$ & 28,414 & 25,370 & 10,338 & 9,230 & 41.1 & 5.3 & 46.4 \\
\hline $\begin{array}{l}\text { S-coated Urea } 1255 \\
(21.4 \% \text { coating) } \\
\text { once a year }\end{array}$ & 28,157 & 25,140 & 10,808 & 9,650 & 49.2 & 10.0 & 59.2 \\
\hline $\mathrm{LSD}^{05}$ & 3,427 & 3,060 & 1,176 & 1,050 & 17.9 & 6.3 & 21.9 \\
\hline
\end{tabular}

${ }^{1} 336 \mathrm{~kg} / \mathrm{ha}$ (300 lb/acre) of $\mathrm{N}$ were applied during the first year and none during the second year.

compounds was applied at the rate of $493 \mathrm{~kg} / \mathrm{ha}$ (440 lb/acre) yearly, and $\mathrm{N}$ at the rate of $672 \mathrm{~kg} / \mathrm{ha}$ (600 lb/acre) yearly.

During the second year, $\mathrm{N}$ and $\mathrm{K}$ fertilization was discontinued in the respective experiments with these nutrients, but the other fertilizer elements continued to be applied as during the first year. During the second year the grass continued to be harvested every 60 days and forage samples analyzed for $\mathrm{N}$ and $\mathrm{K}$.

\footnotetext{
${ }^{4}$ Possibly a Puerto Rico bermudagrass cultivar.
} 


\section{RESULTS AND DISCUSSION}

The soil contained considerable quantities of available $\mathrm{N}$ and $\mathrm{K}$ as evidence by the lack of a strong response to applications of these nutrients during the first year (tables 2 and 3). Yields were much lower during the second year when rainfall was less abundant.

First year yields were not increased by urea in one application but were increased by urea applied in six applications and by the various S-coated urea compounds in one application (table 2). Applying urea in six applications increased yields over those obtained with one application. However, the S-coated urea compounds applied once yearly did not

TABLE 3.-Efficiency of various forms of $\mathrm{KCl}$ applied to stargrass growing on an Ultisol in the humid mountain region of Puerto Rico

\begin{tabular}{|c|c|c|c|c|c|c|c|}
\hline \multirow{3}{*}{ Treatment ${ }^{1}$} & \multicolumn{4}{|c|}{ Yield of dry forage } & \multicolumn{3}{|c|}{$\begin{array}{l}\text { Fertilizer } N \text { recovered } \\
\text { in forage }\end{array}$} \\
\hline & \multicolumn{2}{|c|}{ First year } & \multicolumn{2}{|c|}{ Second year } & \multirow{2}{*}{$\begin{array}{c}\begin{array}{c}\text { First } \\
\text { year }\end{array} \\
?\end{array}$} & \multirow{2}{*}{$\begin{array}{c}\text { Second } \\
\text { year }\end{array}$} & \multirow{2}{*}{ Total } \\
\hline & $\mathrm{Kg} / \mathrm{ha}$ & Lb/acre & $K g / h a$ & Lblacre & & & \\
\hline No K applied & 21,493 & 19,190 & 10,864 & 9,700 & - & - & - \\
\hline $\begin{array}{l}\mathrm{KCl} \text { in one applica- } \\
\text { tion yearly }\end{array}$ & 23,654 & 21,120 & 16,576 & 14,800 & 42.5 & 18.0 & 60.5 \\
\hline $\begin{array}{l}\mathrm{KCl} \text { in six applica- } \\
\text { tions yearly }\end{array}$ & 26,656 & 23,800 & 19,566 & 17,470 & 52.7 & 46.6 & 99.3 \\
\hline $\begin{array}{l}\text { S-coated } \mathrm{KCl} 1015 \\
(22.5 \% \text { coating) } \\
\text { once a year }\end{array}$ & 24,405 & 21,790 & 17,640 & 15,750 & 48.4 & 36.6 & 85.0 \\
\hline $\begin{array}{l}\text { S-coated KCl } 1215 \\
(31.6 \% \text { coating) } \\
\text { once a year }\end{array}$ & 25,928 & 23,150 & 20,429 & 18,240 & 53.0 & 38.9 & 91.9 \\
\hline $\begin{array}{l}\mathrm{S} \text {-coated } \mathrm{KCl} 1000 \\
(31.4 \% \text { coating }) \\
\text { once a year }\end{array}$ & 24,685 & 22,040 & 16,867 & 15,060 & 44.3 & 26.6 & 70.9 \\
\hline $\mathrm{LSD}^{05}$ & 3,427 & 3,060 & 2,408 & 2,150 & 18.6 & 19.0 & 32.3 \\
\hline
\end{tabular}

\footnotetext{
${ }^{1} 493 \mathrm{~kg} / \mathrm{ha}$ (440 lb/acre) of $\mathrm{K}$ were applied during the first year and none during the second year.
}

increase yields above those obtained with urea in one application. Similar yields were obtained with the various S-coated compounds and with urea applied six times yearly.

Urea in one application during the first year did not increase second year yields. Higher yields were obtained during the second year when urea had been put on in six applications during the previous year or as S-coated compounds 1415 and 1255 in one application during the previous year than with no $\mathrm{N}$ fertilization or urea in one application during the year. 
Recovery of fertilizer $\mathrm{N}$ in the forage during the first year was similar for all treatments except for compound 1255 which resulted in a higher recovery than one application of uncoated urea.

Urea in six applications and compounds 1415 and 1255 in one application during the first year resulted in higher recovery of fertilizer $N$ during the second year.

Total recovery of fertilizer $\mathrm{N}$ during the 2 years was higher when urea was applied in six applications during the first year or when compounds 1415 and 1255 were applied in one application than when uncoated urea was applied once. There was no difference in recovery of fertilizer $\mathrm{N}$ between the various $\mathrm{S}$-coated urea compounds in one application and urea in six applications.

In the $\mathrm{K}$ experiment, first year yields were increased by $\mathrm{KCl}$ in six applications and by S-coated compound 1215 in one application, but not by $\mathrm{KCl}$ in one application yearly (table 3 ). There was no difference in yields obtained with $\mathrm{KCl}$ in one or six applications and the various S-coated compounds applied once a year.

During the second year, much higher yields were obtained when $\mathrm{K}$ in the various forms had been applied during the previous year. Higher yields were produced with $\mathrm{KCl}$ in six applications and with compound 1215 in one application than with one application of $\mathrm{KCl}$. Compound 1000 resulted in lower second year yields than did compound 1215 or $\mathrm{KCl}$ in six applications yearly.

During the first year the various $\mathrm{K}$ compounds resulted in similar recoveries of fertilizer $\mathrm{K}$ in the forage. Recovery of fertilizer $\mathrm{K}$ during the second year was higher with $\mathrm{KCl}$ in six applications or compound 1215 in one application during the previous year than with $\mathrm{KCl}$ in one application. $\mathrm{KCl}$ in six applications during the previous year and compounds 1015 and 1215 in one application resulted in similar recovery rates of fertilizer $\mathrm{K}$ during the second year. Compound 1000 in one application during the previous year resulted in lower recovery of fertilizer $\mathrm{K}$ during the second year than did $\mathrm{KCl}$ in six applications.

Total recovery of fertilizer $\mathrm{K}$ over both years exceeded $60 \%$ in all cases. $\mathrm{KCl}$ in six applications resulted in higher recovery of fertilizer $\mathrm{K}$ than with one application. There was no difference in recovery of $\mathrm{K}$ with $\mathrm{KCl}$ in six applications and the various S-coated compounds applied once, nor did these compounds result in higher recoveries than did $\mathrm{KCl}$ in one application.

\section{RESUMEN}

Se determinó la eficacia de varios compuestos de urea y de cloruro de potasio recubiertos con azufre cuando se aplicaron a la yerba Estrella 
sembrada en un suelo Ultisol bajo condiciones típicas de los trópicos húmedos. La aplicación de nitrógeno en forma de urea en seis aplicaciones al año o una aplicación anual de los compuestos de urea recubiertos con azufre (T.V. 1415 y 1255) lograron una recuperación mayor de nitrógeno del forraje en contraste con la urea en una sola aplicación al año.

La aplicación de potasio en forma de cloruro de potasio en seis aplicaciónes al año arrojó un porcentaje mayor de potasio recuperable en el forraje, que cuando se aplicó todo de una sola vez. Los varios compuestos recubiertos con azufre en una aplicación no arrojaron porcentajes de recuperación de potasio en el forraje más elevados que el obtenido con cloruro de potasio en una aplicación.

\section{LITERATURE CITED}

1. Caro-Costas, R., Abruña, F., and Figarella, J., Effect of nitrogen rates, harvest interval and cutting height on yield and composition of Stargrass in Puerto Rico, J. Agr. Univ. P.R. 56(3): 267-79, 1972.

2. — - — - - The yield and composition of five grasses growing in the humid mountains of Puerto Rico as affected by nitrogen fertilization, season and harvest procedure, J. Agr. Univ. P.R. 44(3): 107-20, 1960.

3. Vicente-Chandler, J., Fertilization of humid tropical grasslands, p 277-298. In: D. A. Mays, led] Forage Fertilization. Amer. Soc. Agron. Madison, Wis. 1974.

4. - Caro-Costas, R., and Silva, S., Effects of nitrogen fertilization and frequency of cutting on the yield and composition of Pangola grass in Puerto Rico, J. Agr. Univ. P.R. 45(1): $37-45,1961$.

5. - and Pearson, R. W., Nitrogen fertilization of hot climate grasses, Soil Conserv. Mag., 25(12): 269-72, 1960 .

6. - C Caro-Costas, R., Abruña, F., and Rodriguez, J. A., Effect of two cutting heights, four harvest intervals and five nitrogen rates on vield and composition of Congo grass under humid tropical conditions, J. Agr. Univ. P.R. 56(3): 280-91, 1972.

7. - Caro-Costas, R., and Figarella, J., Effects of nitrogen fertilization and frequency of cutting on the yield of: I. Napier grass, II. Guinea grass, III. Para grass, J. Agr. Univ. P.R. 43(4): 215-48, 1959.

8. - Caro-Costas, R., and Figarella, J., The effect of nitrogen fertilization and frequency of cutting on the yield and composition of three tropical grasses, Agron. J. 51(4): 202-6, 1959.

9. —- Abruña, F., Caro-Costas, R., Figarella, J. Silva, S., and Pearson, R. W., Intensive grasslands management in the humid tropics of Puerto Rico, Agr. Exp. Sta. Univ. P.R. Bull. 233, Feb. 1974

10. —- Pearson, R. W., Abruña, F., and Silva, S., Potassium fertilization of intensively managed tropical grasses under humid tropical conditions, Agron. J. 54(5): 450-3, 1962. 